\title{
RELATIONSHIP BETWEEN QUALITY OF LIFE AND RADIOLOGICAL PARAMETERS AFTER HALLUX VALGUS CORRECTION
}

\section{RELAÇÃO ENTRE A QUALIDADE DE VIDA E PARÂMETROS RADIOGRÁFICOS APÓS CORREÇÃO DO HÁLUX VALGO}

\author{
Henrique Mansur ${ }^{1,2}$ (D), Vinicius Cardoso ${ }^{2}$ (D), Thomas Nogueira ${ }^{2}$ (i), Isnar Castro ${ }^{2}$ (i) \\ 1. Universidade de Brasília, Brasília, DF, Brazil. \\ 2. Instituto Nacional de Traumatologia e Ortopedia, Rio de Janeiro, RJ, Brazil.
}

\section{ABSTRACT}

Objective: To evaluate the correlation between postoperative quality of life and the severity of hallux valgus deformity. Methods: A total of 23 patients underwent moderate $(n=14)$ and severe $(\mathrm{n}=9)$ hallux valgus $(\mathrm{HV})$ surgical correction with the Scarf technique between January 2010 and December 2012. The mean follow-up time was 60 months. Participants answered the SF-36 quality of life assessment questionnaire and their radiographs were evaluated at three different moments (preoperative, 1 and 5 years after surgery). Statistical analysis was performed with a maximum 5\% significance level. Results: The sample consisted of two men and 21 women, aged 58.7.SF-36 mean value was 75.73 and the metatarsophalangeal and interphalangeal angles improved significantly at the three moments $(p<0.05)$. SF-36 showed no statistical difference between patients with moderate or severe HV ( $p>0.05)$. No correlations were found between quality of life and pre and postoperative radiographic angles. Conclusion: Patients with moderate and severe hallux valgus submitted to surgical correction had a very good quality of life and a significant improvement in radiographic parameters. However, these variables were not correlated. Level of Evidence II, Retrospective study.

Keywords: Hallux Valgus. Osteotomy. Quality of Life.

\section{RESUMO}

Objetivo: Avaliar a correlação entre qualidade de vida pós-operatória e a gravidade da deformidade do hálux valgo. Métodos: 23 pacientes foram submetidos à correção cirúrgica do hálux valgo (HV) moderado $(n=14)$ e grave $(n=9)$ pela técnica de Scarf, entre janeiro de 2010 e dezembro de 2012. O tempo mínimo de acompanhamento foi de 60 meses. Os participantes responderam ao questionário de avaliação de qualidade de vida SF-36 e foram avaliadas suas radiografias em três momentos distintos (pré-operatório, 1 e 5 anos de pós-operatório). A análise estatística foi realizada com nível de significância máximo de 5\%. Resultados: A amostra contou com 2 homens e 21 mulheres, com média de idade 58,7 anos. O valor médio do SF-36 foi 75,73 e os ângulos metatarsofalangiano e interfalangiano apresentaram melhora significativa nos momentos avaliados $(p<0,05)$. O SF-36 não mostrou diferença estatística entre os pacientes com HV moderado ou grave $(p>0,05)$. Não houve correlações entre a qualidade de vida e os ângulos radiográficos pré e pós-operatórios. Conclusão: Os pacientes com hálux valgo moderado e grave submetidos à correção cirúrgica apresentaram qualidade de vida considerada muito boa e tiveram significativa melhora dos parâmetros radiográficos. Contudo, não houve associação entre essas variáveis. Nível de Evidência II, Estudo retrospectivo.

Descritores: Hallux Valgus. Osteotomia. Qualidade de Vida.

Citation: Mansur H, Cardoso V, Nogueira T, Castro I. Relationship between quality of life and radiological parameters after hallux valgus correction. Acta Ortop Bras. [online]. 2020;28(2):65-8. Available from URL: http://www.scielo.br/aob.

\section{INTRODUCTION}

Hallux valgus $(\mathrm{HV})$ is a deformity prevalent in $23 \%$ of the adult population aged between 18 and 65 and in $35.7 \%$ of those above 65 , especially women. In addition to aesthetic deformity, most patients experience pain in the first metatarsophalangeal joint, and for $30 \%$ of them, wearing footwear is difficult, which leads to worse quality of life. ${ }^{1-4}$

Several surgical techniques are described to correct the various degrees of deformity, allowing the performance of soft tissue balancing procedures to surgeries involving osteotomies and arthrodeses. ${ }^{4-6}$ Burutaran and Zygmunt originally described the Scarf technique, and Weil and Barouk later popularized it. It is a Z osteotomy to realign the first metatarsal bone, widely used to correct different degrees of HV deformity. ${ }^{7-11}$

Most articles published on the topic compare the results between the different surgical techniques, evaluating the degree of radiographic correction, relapse rates and complications. Data such as pain and range of motion of the first metatarsalopharlangean

All authors declare no potential conflict of interest related to this article.

The study was conducted at the Department of Foot and Ankle Surgery of Instituto Nacional de Traumatologia e Ortopedia.

Correspondence: Henrique Mansur. Área Militar do Aeroporto Internacional de Brasília, Lago Sul, Brasília, DF, 71607-900. henrimansur@globo.com 
joint are commonly used by surgeons to evaluate the postoperative outcome. ${ }^{10,12}$ However, surgeon and patient diverge on their perception. Often, although with a residual deformity, patients are highly satisfied. SF-36 score, when evaluating the psychometric properties of the patient's quality of life, allows a broader analysis of the postoperative outcome of bunion correction surgery from the patient's point of view. ${ }^{13-16}$

Studies evaluating the quality of life of patients with hallux valgus and, mainly, relating quality of life to the degree of radiological correction are scarce. ${ }^{13,14}$ Thus, this work aims to evaluate the correlation between quality of life and radiographic parameters obtained after hallux valgus surgical correction using the Scarf technique. Our hypothesis is that even patients with residual radiographic deformities improve their quality of life after surgery. To know this correlation endorses the importance of the deformity clinical correction rather than of the radiographic aspect.

\section{METHODS}

This study was approved by the Institution Research Ethics Committee. A study was conducted with all patients submitted to moderate and severe HV surgical correction by Scarf technique associated with soft tissue release between January 2010 and December 2012 to obtain a cohort of patients with a minimum follow-up of five years. Different specialists from the foot and ankle surgery group of the institution performed the surgeries and all patients followed the same postoperative protocol and signed the informed consent form.

Patients without all necessary imaging tests, patients with mild deformities, those submitted to deformity correction with other techniques, revision surgeries or bilateral correction were excluded. Besides, patients who disagreed to participate in the study were removed.

Patients who met the inclusion and exclusion criteria were invited to participate in the study. The characteristics recorded were sex, age at the time of surgery and operated foot. Quality of life was quantified applying the Medical Outcomes Study 36-Item Short-Form (SF-36). The questionnaire has 36 items, divided into eight scales (physical functioning, role limitations due to physical health, pain, general health, energy/fatigue, social functioning, emotional well-being, and role limitations due to emotional problems), with scores ranging from zero (worst general health status) and 100 (best health status). The form involves aspects related to disease consequences, it has already been validated for the Portuguese language in Brazil and proved to be reliable to evaluate the results of hallux valgus correction surgery. ${ }^{17-20}$ All participants were evaluated by the lead researcher, who did not participate in the surgery of any of them.

\section{Radiographic analysis}

Foot radiographs in orthostasis at dorsoplantar incidences and profile were performed by the patients before surgery, about one and five years after surgical correction. The radiographic parameters evaluated and compared in the three moments were the following:

- metatarsophalangeal angle (MPA) ${ }^{21}$ : angle formed by the lines that bisect the diaphysis of the first metatarsal and of the hallux proximal phalanx;

- Intermetatarsal angle (IMA) ${ }^{21}$ : angle formed by the lines that bisect the diaphyses of the first and second metatarsals.

Each angle was measured twice by the same examiner, with a one-week interval between the evaluations, and calculated in degrees with the angular measurement tool of the Dicom Viewer software, version 3.0.0®, in the dorsoplantar incidence with load.
The patients were separated into two groups according to radiographic parameters. The moderate hallux valgus group included patients with intermetatarsal angle between $11^{\circ}$ and $16^{\circ}$ or metatarsophalangeal between $20^{\circ}$ and $40^{\circ}$; and the severe hallux valgus group included those with intermetatarsal angle higher than $16^{\circ}$ or metatarsophalangeal higher than $40^{\circ}$, according to Couglin's criteria. ${ }^{21,22}$ Demographic characteristics, final values of SF-36 score, and radiographic parameters were compared between the two subpopulations.

\section{Statistical analysis}

Continuous variables were reported as mean \pm standard deviation and were compared between moderate and severe HV groups and between different pre and postoperative moments. When repeated measurements of the same variable were normal, we compared two of them using the paired Student t-test and then three measurements with the ANOVA test for repeated measurements, with the post-hoc corrections of Bonferroni and Tukey to compare means. When they did not follow normal distribution, we compared two measurements with the Wilcoxon nonparametric test and three repeated measurements using the Kruskal-Wallis test. The assumption of normality for continuous variables was evaluated with the Kolmogorov-Smirnov (KS) and Shapiro-Wilk (SW) tests. The correlational research between two quantitative variables was performed by calculating the Spearman's rank-order correlation coefficient or Pearson Test. Based on the collected data, a database was built in a spreadsheet to analyze them with the IBM SPSS (Statistical Package for the Social Science) program, version 21.0, and with Microsoft Excel. All discussions considered a 5\% (0.05) maximum significance level.

\section{RESULTS}

A total of 23 patients met the inclusion and exclusion criteria. Nine patients (39.1\%) had severe HV and 14 (60.9\%), moderate HV. Of the patients with severe $\mathrm{HV}$, six had MPA $>40^{\circ}$ and three had IMA higher than $16^{\circ}$. The patients' mean age at the time of surgery was $58.7 \pm 8.99$ (39-76 year-olds), 57.4 in the severe group, and 59.5 in the moderate group. This result showed no statistical difference $(p>0.05)$ (Table 1).

Table 1. Baseline characteristics of the total sample and per subgroup.

\begin{tabular}{|c|c|c|c|c|c|c|}
\hline & Mean & Max & Min & SD & Moderate HV & Severe HV \\
\hline Sample & \multicolumn{4}{|c|}{ total $(n=23)$} & $n=14$ & $n=9$ \\
\hline Sex & \multicolumn{4}{|c|}{$13 \mathrm{~W} 11 \mathrm{M}$} & $16 \mathrm{~W} 0 \mathrm{M}$ & $7 \mathrm{~W} 2 \mathrm{M}$ \\
\hline Side & \multicolumn{4}{|c|}{ 12R 12L } & $10 \mathrm{R} 4 \mathrm{~L}$ & $5 \mathrm{R} 4 \mathrm{~L}$ \\
\hline Age & 58.7 & 76 & 39 & 8.99 & 59.5 & 57.4 \\
\hline SF-36 & 75.7 & 91 & 33.4 & 15.77 & 73.3 & 79.5 \\
\hline
\end{tabular}

After a 60-month minimum follow-up time, the total sample SF-36 was 75.7 (SD \pm 15.77 ) and per subgroup it was 79.5 and 73.3, respectively for severe and moderate HV. This difference had no statistical significance ( $p>0.05)$.

The values found when measuring the metatarsophalangeal angle in the preoperative phase, one and five years after surgery, showed significant improvement $(p<0.05)$ in all three moments. Regarding the intermetatarsal angle, the initial values improved considerably one year after surgery and these values also improved after five years $(p<0.05)$. However, the difference between the initial values and after five years was insignificant $(p>0.05)$ (Table 2 and Figure 1). 
Table 2. Variation of radiographic parameters in the pre and postoperative period of patients submitted to HV correction with the Scarf technique.

\begin{tabular}{c|c|c|c|c|c|c}
\hline & Mean & Max & Min & SD & Moderate HV & Severe HV \\
\hline MPA & 33.9 & 50 & 20 & 8.62 & 28.5 & 42.4 \\
\hline MPA1 & 13.9 & 26 & 2 & 6.19 & 12 & 16.9 \\
\hline MPA5 & 18.5 & 41 & 2 & 8.90 & 17.4 & 20.2 \\
\hline IMA & 14.8 & 19 & 6 & 3.00 & 13.4 & 17.1 \\
\hline IMA1, 2011 & 7.7 & 14 & 2 & 2.95 & 6.8 & 9.1 \\
\hline IMA5 & 8.8 & 14 & 2 & 3.27 & 8.4 & 9.4 \\
\hline
\end{tabular}

Caption: HV: hallux valgus; SD: standard deviation; MPA: metatarsal angle; MPA1: one year after surgery; MPA5: five years after surgery; IMA: intermetatarsal angle.

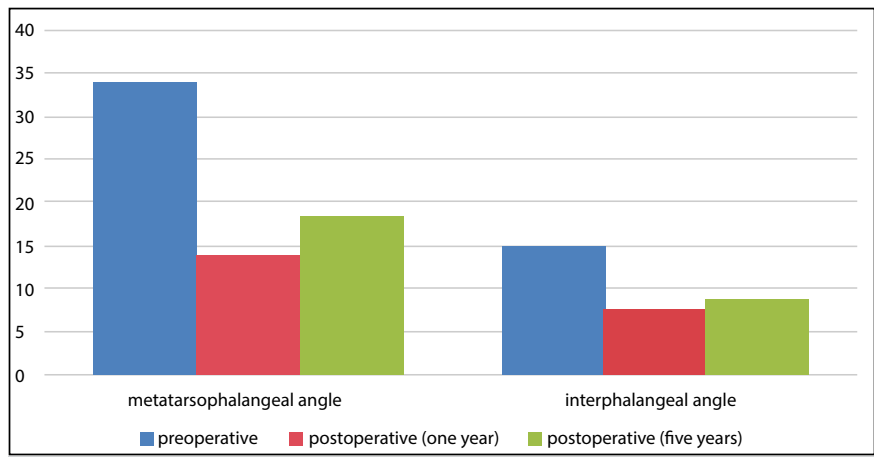

Figure 1. Pre and postoperative radiographic parameters to $\mathrm{HV}$ correction with the Scarf technique.

The quality of life (SF-36) of patients five years after surgery and the values of radiographic parameters (MPA and IMA) preoperatively, one and five years after surgery $(p>0.05)$ were not correlated. Similarly, SF-36 and the patients' age at the time of surgery were not correlated $(p>0.05)$.

\section{DISCUSSION}

This study aimed to determine the correlation between quality of life (QoL) and radiographic parameters after Scarf surgery for HV correction. Our initial hypothesis has been confirmed. We found no correlation between the SF-36 values and the radiographic parameters measured in the late postoperative period. In addition, no differences in QoL were found between patients who had moderate and severe deformities. Our findings serve for surgeons to care more about clinical criteria than radiographic when evaluating their postoperative results.

Scarf technique is widely used especially for moderate to severe deformities, presenting great correction power. ${ }^{7,10,23,24}$ Our patients' metatarsophalangeal and interphalangeal angles improved significantly. MPA was significantly lower $(p<0.05)$ than the preoperative period at all postoperative moments; IMA has improved significantly after one year $(p<0.05)$, which remained improving after five years, but without relevance $(p>0.05)$. Accordingly, Choi et al. ${ }^{23}$ evaluated 53 feet operated with the technique and all radiographic changes showed statistically significant improvement. The difference is that these authors had a 24-month mean follow-up, while in this study it was 60 months.

The SF-36 score sum in our work showed a mean value of 75.7 points, with no statistical difference $(p>0.05)$ between the groups of patients with moderate and severe hallux valgus. According to the Spanish version of SF-36, adapted by Caporicci and Neto, ${ }^{25}$ the final score was divided into: $0=\mathrm{Bad}$; from 0 to $25=$ Regular; from 26 to $61=$ Good; from 62 to $84=$ Very Good, and from 85 to $100=$ Excellent. Thus, we can consider that after the mean time of five years, the operated patients' quality of life was very good. ${ }^{17,21}$ Menz et $\mathrm{a}^{19}$ evaluated patients with hallux valgus and compared clinical deformity and QoL with SF-36. They found a reduction in QoL when deformity worsened. Lopez et al. ${ }^{26}$, after evaluating 100 women with $\mathrm{HV}$, confirmed a relationship between QoL and the bunion deformity. However, these authors used the Manchester scale to measure foot deformity, while our study used objective angular parameters measured on radiographs. In accordance with our results, other authors 27,28 found no relationship between the degree of radiographic deformity and the score obtained in the SF-36, proving the relevance of SF-36 to evaluate the results of hallux valgus surgeries. We can see a correlation between worse quality of life and HV deformity when it is clinically analyzed. It is different when we consider radiographic parameters; however, literature has no consensus. Lazarides et al. ${ }^{29}$, preoperatively evaluating radiographs of 22 patients together with SF-36, attested the more severe the deformity, the worse the QoL.

Our study has some limitations, such as sample size, although it is compatible with the number of patients in other studies. In addition, the SF-36 evaluation at one single moment limited us in identifying changes in the patients' quality of life in an evolutionary way. The studies on the subject show hallux valgus cripples QoL when clinical criteria based on patients' impressions are analyzed. On the other hand, articles that use angular measurement in their methodology report no relationship between deformity and QoL. Although this was not the objective of our work, we infer that sometimes HV hypocorrection aiming at a better aesthetic result, especially in more severe cases, can bring more satisfactory results to the patient.

\section{CONCLUSION}

The quality of life of patients submitted to the Scarf technique for moderate and severe hallux valgus correction has no correlation with postoperative radiographic parameters after five years of surgery.

AUTHORS' CONTRIBUTION: Each author contributed individually and significantly to the development of this article. HM: writing and review of the article and approval of the final version; VC: idealization and planning of the activities that led to the study, writing of the article and approval of the final version; TN: writing and review of the article and approval of the final version; IC: text review and approval of the final version.

\section{REFERENCES}

1. Menz HB, Lord SR. Gait instability in older people with hallux valgus. Foot Ankle Int. 2005;26(6):483-9.

2. Roddy E, Zhang W, Doherty M. Prevalence and associations of hallux valgus in a primary care population. Arthritis Rheum. 2008;59(6):857-62.

3. Nix S, Smith M, Vicenzino B. Prevalence of hallux valgus in the general population: a systematic review and meta-analysis. J Foot Ankle Res. 2010;3:21.

4. Robinson AH, Limbers JP. Modern concepts in the treatment of hallux valgus. J Bone Joint Surg Br. 2005;87(8):1038-45.
5. López DL, Callejo González L, Losa Iglesias ME, Canosa JLS, Sanz DR, Lobo CC, Vallejo RBB. Quality of life impact related to foot health in a sample of older people with hallux valgus. Aging Dis. 2016;7(1):45-52.

6. Okuda R, Kinoshita M, Yasuda T, Jotoku T, Kitano N, Shima H. The shape of the lateral edge of the first metatarsal head as a risk factor for recurrence of hallux valgus. J Bone Joint Surg Am. 2007;89(10):2163-72.

7. Molloy A, Widnall J. Scarf osteotomy. Foot Ankle Clin. 2014;19(2):165-80. 
8. Burutaran JM. Hallux valgus y cortedad anatomica del primer metatarsano (correction quirurgica). Actual Med Chir Pied. 1976;XIII:261-6.

9. Zygmunt KH, Gudas CJ, Laros GS. Z-bunionectomy with internal screw fixation. J Am Podiatr Med Assoc. 1989;79(7):322-9.

10. Borrelli AH, Weil LS. Modified scarf bunionectomy: our experience in more than 1000 cases. J Foot Surg. 1991;30:609-12.

11. Barouk LS. Scarf osteotomy of the first metatarsal in the treatment of hallux valgus. Foot Dis. 1991;2:35-48.

12. Thordarson DB, Rudicel SA, Ebramzadeh E, Gill LH. Outcome study of hallux valgus surgery-an AOFAS multi-center study. Foot Ankle Int. 2011;22(12):956-9.

13. Cardoso VT, Mansur H, Castro IM Jr. Avaliação da qualidade de vida e parâmetros radiológicos após a correção do hálux valgo. Sci J Foot Ankle. 2019;13(1):3-9.

14. Klugarova J, Hood V, Bath-Hextall F, Klugar M, Mareckova J, Kelnarova Z Effectiveness of surgery for adults with hallux valgus deformity: a systematic review. JBI Database System Rev Implement Rep. 2017;15(6):1671-710.

15. Baumhauer JF, Mclntosh S, Rechtine G. Age and sex differences between patient and physician-derived outcome measures in the foot and ankle. J Bone Joint Surg Am. 2013;95(3):209-14.

16. Schneider W, Knahr K. Surgery for hallux valgus. The expectations of patients and surgeons. Int Orthop. 2001;25(6):382-5.

17. Ciconelli RM, Ferraz MB, Santos W, Meinão I, Quaresma MR. Tradução para a língua portuguesa e validação do questionário genérico de avaliação de qualidade de vida SF-36. A reliable and valid quality of life outcome measure. Rev Bras Reumatol. 1999;39(3):143-50.

18. Saro C, Jensen I, Lindgren U, Felländer-Tsai L. Quality-of-life outcome after hallux valgus surgery. Qual Life Res. 2007;16(5):731-8.

19. Menz, HB, Roddy E, Thomas E, Croft PR. Impact of hallux valgus severity on general and foot and foot-specific health-related quality of life. Arthritis Care Res (Hoboken). 2011;63(3):396-404.
20. Chen L, Lyman S, Do H, Karlsson J, Adam SP, Young E, et al. Validation of foot and ankle outcome score for hallux valgus. Foot Ankle Int. 2012;33(12):1145-55

21. Couglin MJ. Hallux valgus. J Bone Joint Surg Am. 1996;78(6):932-66.

22. Costa MT, Pinto RZA, Ferreira RC, Sakata MA, Frizzo GG, Santin RAL. Osteotomia da base do I metatarsal no tratamento do hálux valgo moderado e grave: resultados após seguimento médio de oito anos. Rev Bras Ortop. 2009;44(3):247-53.

23. Choi JH, Zide JR, Coleman SC, Brodsky JW. Prospective study of the treatment of adult primary hallux valgus with scarf osteotomy and soft tissue realignment. Foot Ankle Int. 2013;34(5):684-90.

24. Ma Q, Liang X, Lu J. Chevron osteotomy versus scarf osteotomy for hallux valgus correction: a meta-analysis. Foot Ankle Surg. 2018;pii:S1268-7731(18)30418-1.

25. Caporicci S, Neto MFO. Estudo comparativo de idosos ativos e inativos através da avaliação das atividades da vida diária e medição da qualidade de vida. Motri. 2011;7(2):15-24

26. Palomo-López P, Becerro-de-Bengoa-Vallejo R, Losa-Iglesias ME, RodríguezSanz D, Calvo-Lobo C, López-López D. Impact of hallux valgus related of quality of life in women. Int Wound J. 2017;14(5):782-5.

27. Thordarson DB, Ebramzadeh E, Rudicel SA, Baxter A. Age-adjusted baseline data for women with hallux valgus undergoing corrective surgery. J Bone Joint Surg Am. 2005;87(1):66-75.

28. Saro C, Jensen I, Lindgren U, Felländer-Tsai L. Quality-of-life outcome after hallux valgus surgery. Qual Life Res. 2007;16(5):731-8.

29. Lazarides SP, Hildreth A, Prassanna V, Talkhani I. Association amongst angular deformities in hallux valgus and impact of the deformity in health-related quality of life. Foot Ankle Surg. 2005;11(4):193-6. 